


\section{THE UNIVERSITY}

\section{OF ILLINOIS}

\section{LIBRARY}

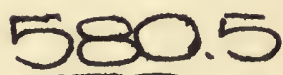

$F B$

$$
\text { v. } 4
$$

islotoct 
Return this book on or before the Latest Date stamped below. A charge is made on all overdue books.

U. of I. Library

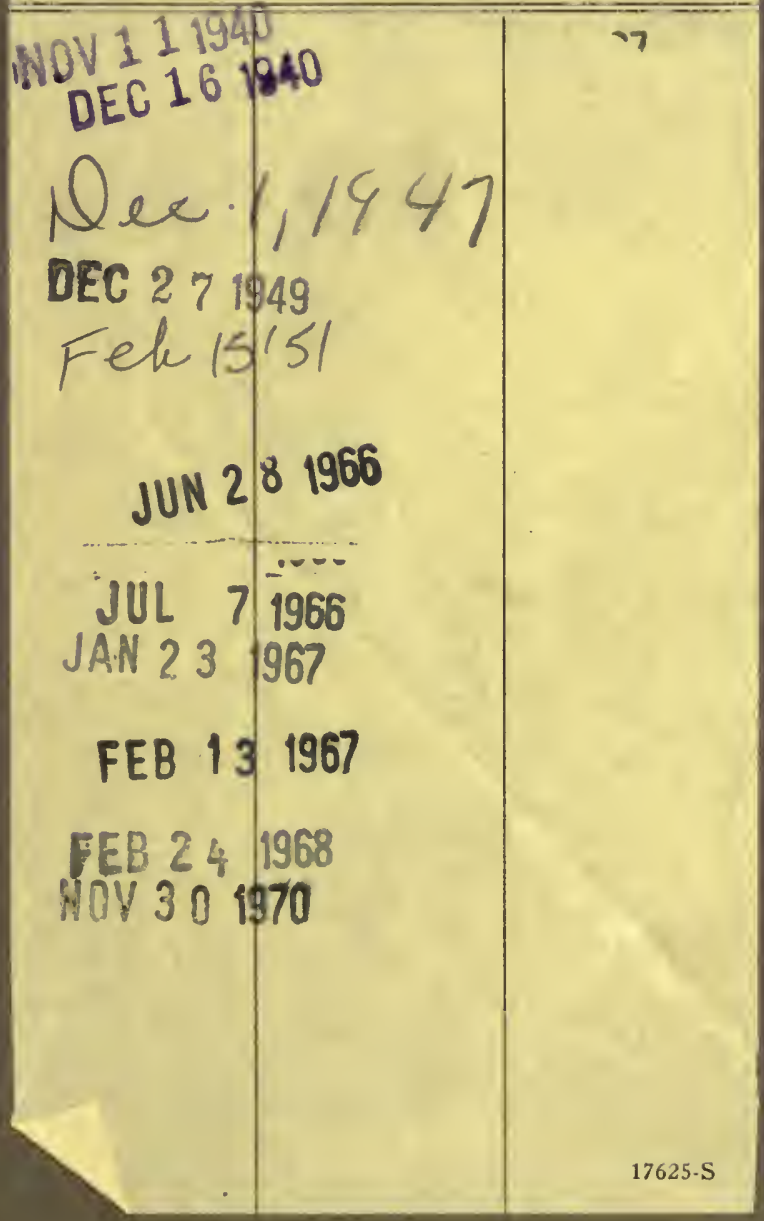




XII. View in the forest on Barro Colorado Island....... I4 8 Base of plant of Renealmia aromatica, showing the inflorescences...................... I 48

XIII. Ophiomeris panamensis, at left, and Leiphaimos albus. . I 50 Apodanthes Flacourtiae, growing on trunk of Xylosma Hemsleyana................... I 50 XIV. Trunk of Zanthoxylum sp., showing the curious flattened corky prickles................... I 54

XV. Base of trunk of Bombacopsis Fendleri, the largest tree of Barro Colorado Island, showing the buttresses.

The palm is Acanthorrhiza Warscewiczii......... ${ }_{5} 6$ Base of a trunk of Ouratea Wrightii............ I 56

XVI. Chara Kenoyeri...................... I60

XVII. Campylopus hondurensis............... 349

XVIII. Bryum Standleyi................... 352

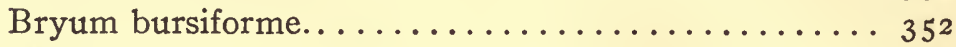

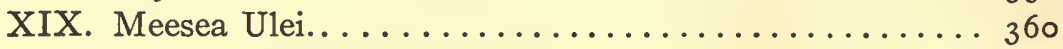

Rhynchostegium patulum................. 360 
Field Museum of Natural History.

\title{
Publication 199.
}

Botanical Series. Vol. IV, No. I.

\section{NEW SPECIES OF XANTHIUM AND SOLIDAGO.}

\author{
BY \\ Charles Frederick Millspaugh \\ AND \\ Earl E. Sherff.
}

Charles Frederick Millspaugh

Curator, Department of Botany.

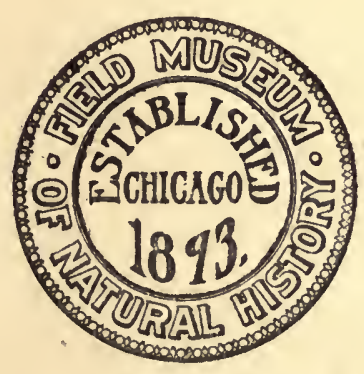

Chicago, U. S. A.

April, I9I8.

\section{Issued}





\section{NEW SPECIES OF XANTHIUM AND SOLIDAGO}

CHARLES F. MillsPaUGH, M.D. and EARL E. SHERFF, Ph.D.

XANThiUm (Tourn.) L.

In determining certain specimens of Xanthium in the Herbarium of the Field Museum, the writers have found the taxonomic status of this genus, as concerns its various species, to be very unsatisfactory at the present time. Múch of the uncertainty in connection with several species arises from the difficulty encountered in the past in identifying the older specific names, names that in a number of cases, at.least, were founded upon heterogeneous material (cf. E. L. Greene, Pittonia 4: 58. 1899; also T. H. Kearney, Bull. Torr. Bot. Club 24: 575. 1897). Another source of confusion in herbaria has been the erroneous identifcation of new and undescribed species with any one of the older, more commonly known species. Still further, we must note the well-known contempt with which common weeds such as Xanthium are so often regarded, a reason that explains the surprisingly small number of herbarium specimens of any one species collected heretofore in a given region.

In I842, Wallroth (K. F. W., Beiträge zur Botanik $\mathrm{I}^{\mathrm{I}}$ : 229; G. G. Walpers, Repert. Bot. Syst. 6: I50. 1846), monographing Xanthium, described five new species for this region of America. One of these, $X$. xanthocarpum, described as having tripartite spines and coming from fields between Staunton and Charlottesville, Virginia, is easily recognized as being Wallroth's North American segregate from $X$. spinosum L. Under $X$. spinosum L., Wallroth ${ }^{1}$ included the plants of southern Europe, and indeed Linnaeus himself had understood this species as European ("Habitat in Lusitania, Monspelii." Sp. P1. Edit. II: I400. I763). But, more recently, this viewpoint has changed. Thus, the Index Kewensis terms $X$. spinosum L. "cosmopolitan." And some other authorities (e. g., A. Gray, Synopt. Fl. N. Amer. I": 253. I884) even treat it as a tropical American species. Wallroth's North American segregate seems to have been ignored uniformly by our manuals, apparently with justice.

${ }^{1}$ We rely upon Walpers' Repertorium (loc. cit.) for Wallroth's diagnoses, etc. 
Wallroth's other four species have been accorded various interpretations by different authors, only one species, $X$. pennsylvanicum, having definitely survived the several reductions to synonomy. ${ }^{1}$ This species appears to be correctly described by Britton and Brown (Illustr. F1., Edit. II, 3: 346, fig. 4I37. I9I3) and still more recently by Shull (Bot. Gaz. 59: 476, fig. 2. I9 15). Robinson and Fernald (Gray's Man., Edit. VII, 829. I908) refer $X$. pennsylvanicum Wallr. doubtfully to $X$. canadense Miller, a species advanced in the eighth edition of Miller's Dictionary but equated in the ninth (posthumous) edition with $X$. orientale L., and likewise equated recently by O. Hoffmann (Engl. and Prantl Natürl. Pflanzenfamilien $4^{\mathrm{v}}$ : 223 . I894), Britton and Brown (loc. cit.), and others. Shull (loc. cit.) maintains the names $X$. pennsylvanicum and $X$. canadense separately for United States material and illustrates each. But by $X$. canadense he means the species figured by Britton and Brown (loc. cit. fig. 4I39) as X. americanum Walt., a plant formerly confused with the European $X$. strumarium L. ${ }^{2}$ To us, however, it seems safer to retain the name $X$. americanum Walt. and to reject the name $X$. canadense Miller, at least until, a thorough and painstaking revision of the entire genus shall have been made.

In the Herbarium of Field Museum are a number of specimens which are clearly conspecific and which we regard as $X$. americanum Walt. As will be seen below, these represent a range extending from Illinois to New York, south to Florida and west to Texas:

Dr. Geo. Vasey, Chicago, Ill. (Herb. Field Mus. catalogue no. 46737I); Earl E. Sherff I826, prairie, Chicago, Ill., Aug. 30, I9I 2 (Herb. Field Mus. cat. no. 435932); F. C. Gates 10024, Hancock County, Ill., Sept. Io, I9 6 (Herb. Field Mus. cat. no. 472764); Harry N. Patterson, vicinity of Oquawka, Ill. (Herb. Field Mus. cat. nos. 209220 and 209230); Elihu Hall, fields, etc., Menard Co., Ill. (Herb. Field Mus. cat. no. 2062I8); idem, I1l. (Herb. Field Mus. cat. no. 453866); A. B. Burgess 365, pasture, Prairie Rhonde, Mich., Sept. 27, I903 (Herb. Field Mus. cat. no. I44710); Dr. Chas. F. Millspaugh, banks of the Susquehanna River, Vestal, N. Y., Sept. ro, I 886 (Herb. Field Mus. cat. no. I8744); Dr. J. T. Rothrock, streets, Philadelphia, Pa., Sept. 22, I877 (Herb. Field Mus. cat. no. 320565); A. A. Heller, on Little Conestoga near Stoneroad's Mill, Lancaster Co., Pa., Oct. 5, I90I (Herb. Field

1 It must be remarked, however, that Wallroth's treatment of the genus, regardless of its merit or demerit, appears to have received all too scanty a study. Gray (loc. cit.) omits all mention of Wallroth's names and so appears to have overlooked them entirely.

2 In passing, we note Shull to say "it is now known that $X$. strumarium has never been introduced into America." But in 1912, Fernald (Rhodora 14: 239.) reported finding a single large plant of "true $X$. strumarium" growing at Revere, Massachusetts. 
Mus. cat. no. 430064); Dr. Arthur Schott, near Georgetown, D. C., Sept. 6, 1863 (Herb. Field Mus. cat. no. 44074); J. M. Greenman 538, along the river near Tygart Junction, Barbour Co., W. Va., Sept. 24, I904 (Herb. Field Mus. cat. no. 345709); A. S. Hitchcock, Key West, Fla., Mar. 28-30, I906 (Herb. Field Mus. cat. no. 230307); anonymus, Lake City, Fla. (Herb. Fla. Agri. Coll. no. r279, Herb. Field Mus. cat. no. 234909); Royal A. Dixon 40, Huntsville, Texas, June 3-12, r9o8 (Herb. Field Mus. cat. no. 237976).

A study of the specimens in the above list shows $X$. americanum to have for its fruiting involucre a bur distinctly ovoid in shape, r.2-r.5 $\mathrm{cm}$. long (exclusive of the beaks), the beaks straight or nearly so, and the entire body tending to be, aside from its prickles, more or less glabrous; the prickles are straight from the base almost to the apex, where they are usually hooked. On comparison with these specimens, we find three sheets of material that show striking departures in certain directions, and a fourth bearing material that is more properly comparable with $X$. pennsylvanicum Wallr., from which it differs, however, in several important respects. As all four of these specimens are completely irreconcilable with any form of Xanthium known to us, they are described herewith as representing new species:

Xanthium leptocarpum Millspaugh \& Sherff sp. nov. P1. I, \& Vff. I \& 5 .

Herba annua, 3-5 dm. alta; caule inermi, superne scabro. Folia alterna, circumambitu plus minusve deltoidea et trilobata, margine dentata, basi triplinervia et cordata aut subtruncata, utrimque setulis adpressis vestita, infra sed non supra minute reticulata, petiolata, petiolis adjectis $7-19 \mathrm{~cm}$. longa, petiolis tenuibus et laminis subaequantibus. Fructus multi, 4-12 simul congregati, anguste cylindricofusiformi, badii, superne sensim angustati et in duo rostra arcuata distantia producti, exteriore facie $18-40$ aculeis $(2-3$ aut rare-4 $\mathrm{mm}$. longis) armati, pubescentes et numerosis punctis resinae punctati uti bases aculeorum et rostrorum; rostris et aculeis ad apicem hamosis, rostris crassioribus et paulo longioribus; fructus corpore (rostris non adjectis) $1.3^{-1.6 \mathrm{~cm}}$. longo, 3.5-5 mm. crasso. Achaenia 2 ; maiore circum $\mathrm{r} .8 \mathrm{~cm}$. longo et $4 \mathrm{~mm}$. lato, 3-costato, levi, base acuminato, rostro abrupte mucronulato.

L. R. Jones, Burlington, Vermont, September 12, 1896 (type in Herb. Field Museum, cat. no. 430860).

This species is very distinct in the appearance of its fruiting involucres. These have a reddish-brown or chestnut color and are narrowly cylindric-fusiform, not ovoid. The prickles are very few in number (18-40) and noticeably far apart. 
Xanthium oligacanthum Piper, a far-western species described from Washington, appears from its description to be nearest this species. But $X$. oligacanthum is described as having the fruiting involucres 5-7 mm. thick, not only $3 \cdot 5^{-5} \mathrm{~mm}$. thick as in our species.

Xanthium arcuatum Millspaugh \& Sherff sp. nov. Pl. II, \& V ff. 2 \& 6.

Herba annua, caule inermi, habitu X. leptocarpo non dissimilis; foliis infra minute et subobscure reticulatis et resina punctatis. Fructus pauciores et crassiores, $2-4$ simul congregati, anguste ovati, apice rostris et facie exteriore numerosis (I00-I70) aculeis armati; rostris rectis aut minime arcuatis, apice hamosis, $3 \cdot 5-5 \mathrm{~mm}$. longis, non pubescentibus sed infra puncta resinae ferentibus; aculeis tenuibus (subrectis aut) maximam partem arcuatis, plus minusve rubro-purpureo tinctis, 4-6 $\mathrm{mm}$. longis, apice hamosis, infra resiniferis ut corpus; corpore (rostris non adjectis) demum I.3-r.5 cm. longo et $5^{-6} \mathrm{~mm}$. crasso. Achenia 2 ; maiore circum $1.8 \mathrm{~cm}$. longo et $5 \mathrm{~mm}$. lato, 3-costato, levi, base obtuse orbiculato, rostro abrupte aristato.

T. F. Lucy, river shores and low places, Chemung County, New York, October I I, I896 (type in Herb. Field Museum, cat. no. 4953).

Not only are the burs more or less of a decidedly reddish-purple shade, but the prickles are very numerous and are mainly flexed or arcuate from the base to the apical hook, not straight as in $X$. americanum. The burs suggest those of $X$. inflexum Mack. \& Bush, but are smaller, of more delicate structure and do not have strongly incurved beaks.

Xanthium cylindricum Millspaugh \& Sherff sp. nov. P1. III, \& V ff. 3 \& 7 . Herba, veri similiter annua; caule inermi. Folia magna, alterna, quibusdam foliis Hibisci militaris Cav. simillima, circumambitu subdeltoideo-ovata, trilobata (et fere hastata) aut quinquelobata, margine dentata, basi triplinervia et cordata aut subtruncata, membranacea, scabra aut tactui etiam fere levia, minute sed perspicue reticulata, setulis adpressis vestita, infra paucis punctis resinae punctata, petiolis adjectis $\mathrm{I} .3-2.5 \mathrm{dm}$. longa, petiolis tenuibus et laminis subaequantibus. Fructus multi, 3-8 simul congregati, cylindrico-fusiformi, rubro-badii, rostris et aculeis armati, punctis minutis resinae punctati, aliter glabri; duobus rostris arcuatis, ad apicem hamosis, 4-5 mm. longis; aculeis (I00-I 50) tenuibus, rubro-badiis, ad apicem hamosis, $2.5-3.5 \mathrm{~mm}$. longis; corpore (rostris non adjectis) I. $4-\mathrm{r} .6 \mathrm{~cm}$. longo, $4-5 \mathrm{~mm}$. crasso. Achenia 2; maiore circum I. $5 \mathrm{~cm}$. longo et $3 \mathrm{~mm}$. lato, 3-costato, levi, base acute orbiculato, apice sensim in rostrum mucronulatum producto.

J.K. Small and A.M.Huger, Chimney Rock to Hendersonville, North Carolina, October 3, I901 (type in Herb. Field Museum, cat. no. 4013 I 2). 
The unique character of the foliage stamps this species as most interesting. The leaves are remarkably like many of those met with on Hibiscus militaris Cav., and undoubtedly give the species an appearance in the field unlike that of any other North American species. The burs have a body distinctly cylindrical, not ovoid, and the beaks are curved.

Xanthium crassifolium Millspaugh \& Sherff sp. nov. P1. IV, \& Vff. 4 \& 8.

Herba, veri similiter annua; caule inermi, superne setulis albis (caulem inferiorem non vidimus) scabro. Folia alterna, crassa et non membranacea, circumambitu subdeltoidea et tri-aut quinquelobata (et foliis quarumdam Malvacearum, exempli gratia Sphaeralcea remota (Greene) Fernald et Althaea officinalis L., simillima), basi triplinervia, multis setulis albis adpressis scabra, numerosis punctis parvis resinae punctata, petiolata, petiolis adjectis $5-17 \mathrm{~cm}$. longa, petiolis laminis subaequantibus; nullis areolis reticulatis manifestis supra aut infra. Fructus singulatim aut $2-3$ simul dispositi, anguste aut sublate cylindrico-fusiformi, badii, superne sensim duo róstra arcuata et hamosa producti; exteriore facie $120-180$ hamosis aculeis $(3.5-5 \mathrm{~mm}$. longis et rostris subaequantibus) armati, pilosi et resina punctati ut aculei ad basim et rostra infra; fructus corpore (rostris non adjectis) demum I.7-1. $8 \mathrm{~cm}$. longo et $6-7.5 \mathrm{~mm}$. crasso; rostris $4-6 \mathrm{~mm}$. longis. Achenia 2 ; maiore circum $2 \mathrm{~cm}$. longo et $6 \mathrm{~mm}$. lato, 5-costato, transverse rugoso, in suum basem orbiculatum et in rostri basem latum angustato abrupte.

B. Mackensen 123, San Antonio, Texas, October 8 and November I5, I9I I (type in Herb. Field Museum, cat. no. 324122); Dr. J. Gregg, 457, Sept. 20, sine loc. ${ }^{1}$ (Herb. Missouri Botanical Garden, no. 8559x).

In certain characters, this species seems nearest Xanthium bubalocarpon Bush, which is described, however, as having the burs ovoid, $2.5-4 \mathrm{~cm}$. long ("including the short beaks"), and $2-3 \mathrm{~cm}$. thick ("including the prickles"), the beaks $6-8 \mathrm{~mm}$. long and the burs even much exceeding in size those of $X$. speciosum Kearney,-a species with burs broader than those of $X$. crassifolium. ${ }^{2}$

In addition to the above four new species, represented in the herbarium of this museum, we find still another among the specimens belonging to the herbarium of the Missouri Botanical Garden:

${ }^{1}$ His numeration appears, however, to place this in Mexico.

${ }^{2}$ On going to press we have received a delayed consignment of plants from the Missouri Botanical Garden. Among these is the type material of $X$. bubalocarpon which we find strikingly distinct: its mammoth burs are not only much larger but more closely and bristly echinate than those of $X$. crassifolium and the leaves are larger and thinner. 
Xanthium acutilobum Millspaugh \& Sherf, sp. nov.

Herba, veri similiter annua; caule inermi, superne setulis albis scabro, setulorum basibus tuberculato-crassatis. Fólia alterna, submembranacea, circumambitu subhastato-triangulata, acute $3-7$-lobata et dentata, basi triplinervia et cordata aut truncata, utrimque setulis albis adpressis vestita et non minutissime reticulata, petiolata, petiolis adjectis $0.6-2.2 \mathrm{dm}$. longa, petiolis tenuibus et laminis subaequantibus. Fructus non numerosi, maximam partem singulatim dispositi, ovatocylindrici, superne sensim in duo rostra producti (rostris minime arcuatis, ad apicem hamosis), demum badii; exteriore facie I $20-180$ hamosis aculeis (qui $3-4.5 \mathrm{~mm}$. longi et infra non solum resiniferi sed etiam sparsim pilosi sunt) armati, numerosis punctis resinae punctati; fructus corpore (rostris non adjectis) demum circum $1.6 \mathrm{~cm}$. longo et $5^{-6} \mathrm{~mm}$. crasso; rostris infra hispidis, circum $5 \mathrm{~mm}$. longis. Achenia 2; maiore circum $2.1 \mathrm{~cm}$. longo et $5 \mathrm{~mm}$. lato; tergo levi sed altero facie 5-costato, corpore sensim in basem acutum et apicem mucronatum angustato.

J. Reverchon, Oak Cliff, Texas, September 2 (type in Herb. Missouri Botanical Garden no. 85603; duplicate sheets in the same herbarium bear the numbers 85470 and 85485 ).

The privilege of examining the Xanthium sheets of the Missouri Botanical Garden comes to us too late to allow of the preparation of an illustrative plate of this species in time for this publication. In fruiting involucres $X$. acutilobum resembles $X$. crassifolium, from which it is very distinct, however, in its different-shaped, thinner, and much larger leaves and in the characters of the achene.

\section{Solidago L.}

In the summer of I9I7, a peculiar specimen of Solidago came to our notice. It had been collected by Isaac Holton near Morris, Illinois, September I3, I850, and during all the years since then had remained with merely the name Solidago upon its label. In its inflorescence it suggested at once S. speciosa Nutt., especially the smaller form of that species often termed var. angustata T. \& G. (S. rigidiuscula Porter). But the heads were noticeably smaller than heads of the same degree of maturity in any material of S. speciosa. The leaves did not possess the pronounced reticulation that is so characteristic of the leaves of S. speciosa; and, what was still more striking, the lower leaves were cuneate-oblanceolate in outline and distinctly notched at the apex.

By reference to other material collected by Holton on the same day, it was learned that he had collected at least one plant that day along the Illinois-Michigan canal (Aster sericeus Vent.). Trips were made to Morris on September 8 and September 23, I9I 7 , for the express 
purpose of collecting once more, if possible, this interesting Solidago. An aggregate distance of nearly twenty-five miles was traveled on foot in that vicinity, special attention being given to the flora along the now abandoned canal and the railroad rights-of-way. Elsewhere the land either was under intensive cultivation (or pasturage), or was swampy and unsuited to a species presumably of the prairie. Even the roadsides were found in most cases to have had their native flora more or less entirely exterminated in the past by mowing. ${ }^{1}$ A careful search failed to reveal the plant. We fear that the rapid commercial and agricultural development of the land about Morris, during the few years subsequent to the opening of the Illinois-Michigan Canal in $1848,{ }^{2}$ may have rendered this species extinct.

That a permanent record of the plant may be left, we present a rather full taxonomic description:

Solidago emarginata Millspaugh \& Sherff sp. nov. Pl. VI.

Herba, perennis (?), $\pm 5 \mathrm{dm}$. alta, simplex (forsan ad basim ramosa). Caulis infra subglaber, superne pubescens. Folia alterna, non petiolata, glabra sed margine ciliata, non perspicue reticulata; inferiora cuneatooblanceolata, ad basim angustata sensim, ad apicem valde et perspicue emarginata sinu $\mathrm{I}-4 \mathrm{~mm}$. alto, $2-7 \mathrm{~cm}$. longa et 6-9 $\mathrm{mm}$. lata; superiora linearia aut lineari-lanceolata, utrimque acuminata, $3-7 \mathrm{~cm}$. longa et 4-8 mm. lata, summa cum fasciculis axillaribus foliolorum. Inflorescentia thyrsiforma, $\pm 2 \mathrm{dm}$. longa; racemis multis, gracilibus, suberectis, $2-7 \mathrm{~cm}$. longis; ramulis tenuibus et pubescentibus. Capitula (immatura) oblonga, $2-3.5 \mathrm{~mm}$. alta; bracteis $3-4$-seriatis, lineari-oblongis, non nisi ad apicem pubescentibus, obtusis, ad tergum subcarinatis, exterioribus sensim brevioribus; radiis non observatis; disci flosculis circum ıo; pappi setis in ovario scabridis.

I. F. Holton, near Morris, Illinois, September I3, I850 (type Herb. University of Chicago, in Herb. Field Museum cat. no. 368080).

1 Concerning the peculiar conditions that have been tending toward the extermination of our native prairie species in Illinois, see E. S. Steele, Contrib. U. S. Nat. Herb. 13: 360. 1911.

${ }^{2}$ For various data connected with Morris and vicinity, consult C. O. Sauer, I11. State Geol. Surv. Bull. 27, 1916. 



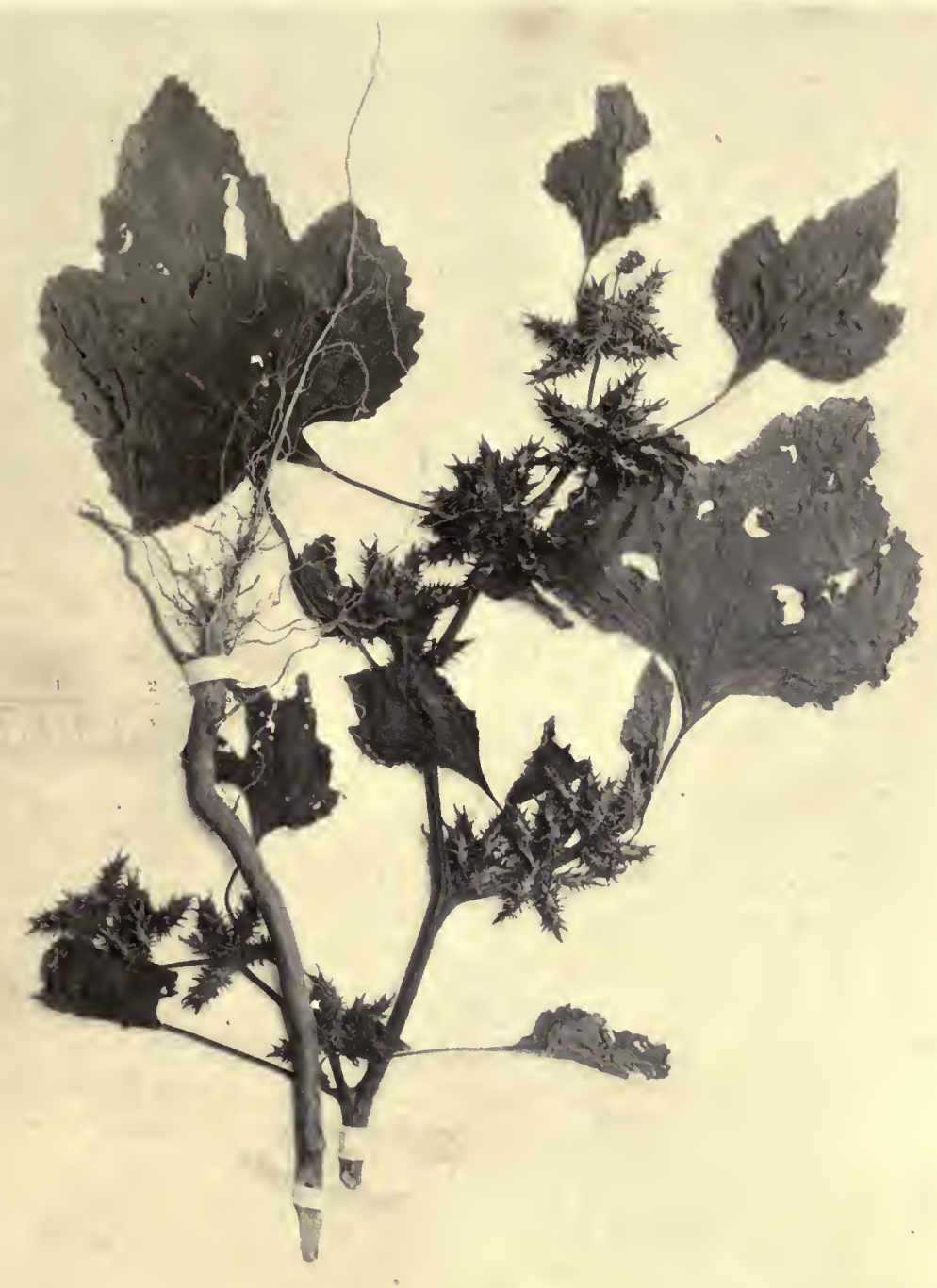





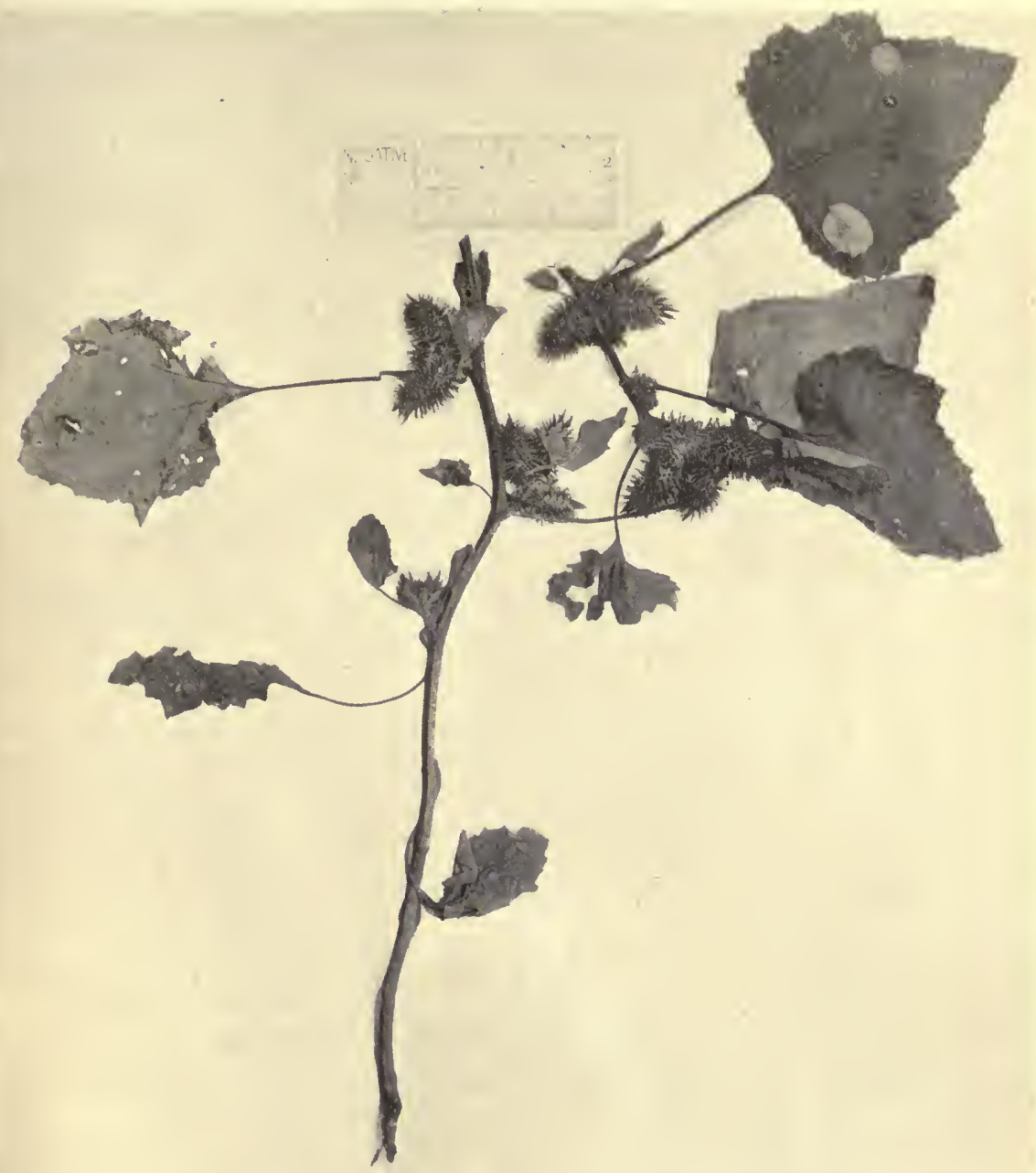





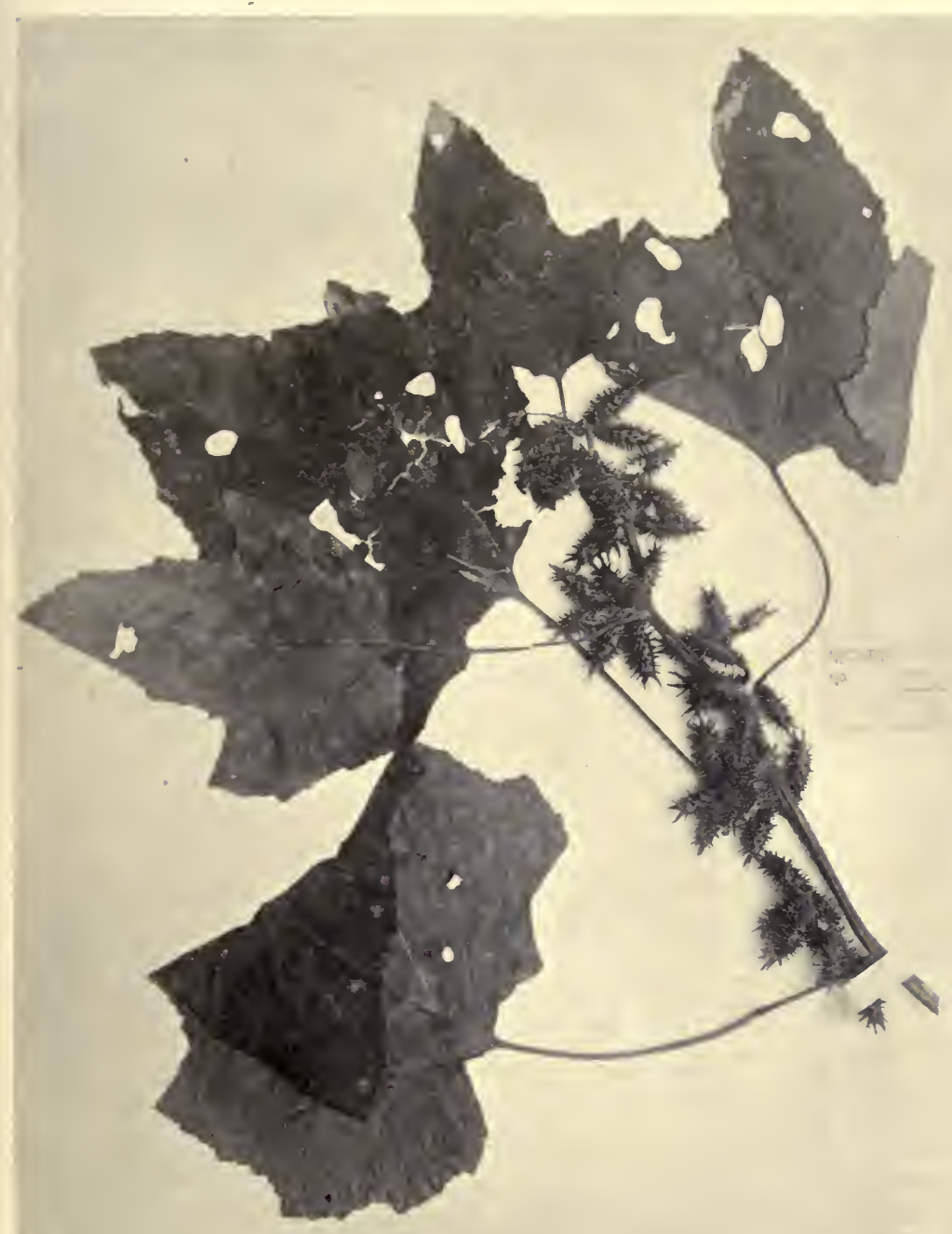

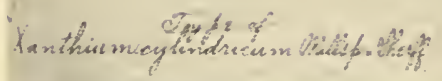





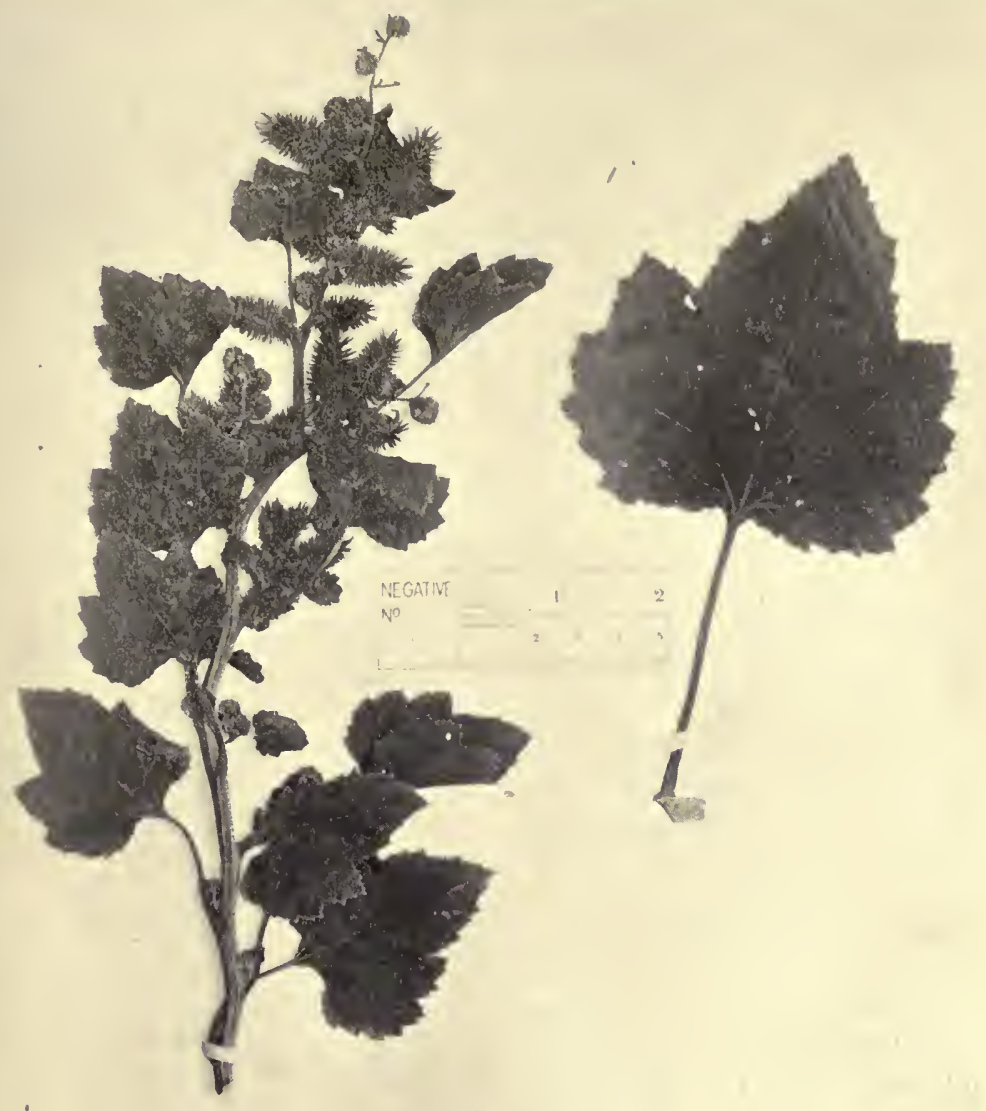

Herbarium of $B$. Mackensen

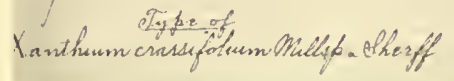



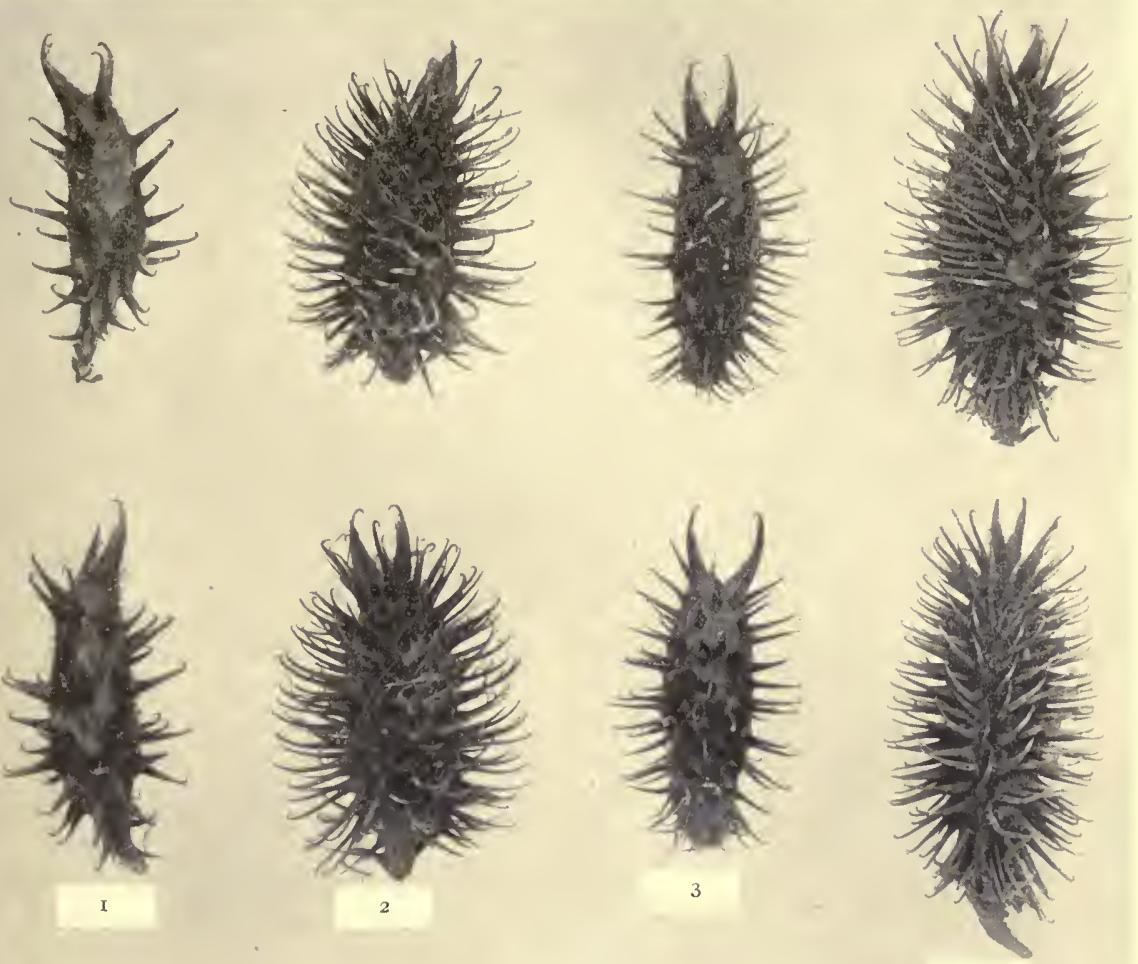

4
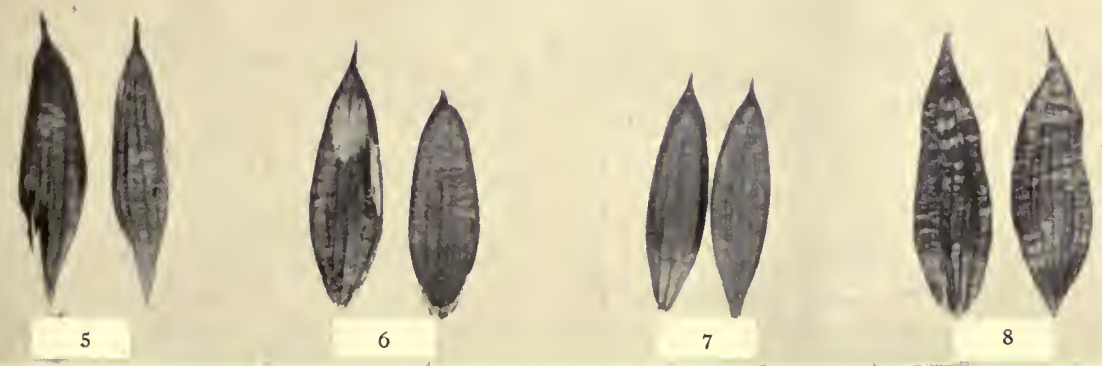

I and 5. X. leptocarpum 2 and $6, X$. arcuatum 3 and $7, X$. cylindricum 4 and $8, \mathrm{X}$. crassifolium (All enlarged $1 / 2$ diameter) 



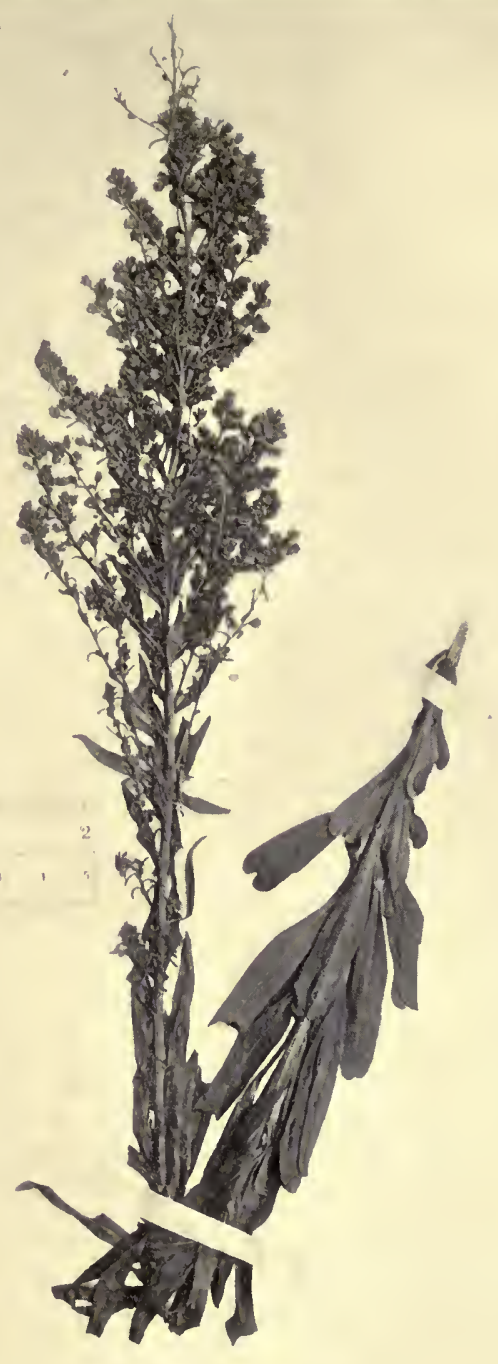

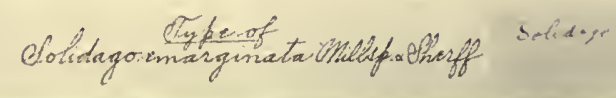



UNIVERSITY OF ILLINOIS-URBANA

$580.5 F 8$

B BOTANYSCH

4

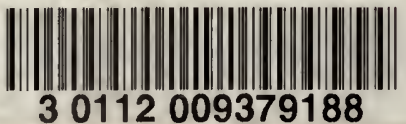

